\title{
Immigration Policy Reform in the United States: Reframing the enforcement discourse to fight human trafficking and promote shared prosperity
}

\author{
Ana Avendaño and Charlie Fanning ${ }^{1}$
}

\begin{abstract}
At the time of this writing, the United States Senate has passed the Border Security, Economic Opportunity, and Immigration Modernization Act (S. 744). The bill is the product of countless political compromises and would significantly transform the U.S. immigration system. This paper explores shortcomings in U.S. immigration policy, deconstructs provisions in the bill, and makes policy proposals that would protect and empower migrants who interface with the U.S. immigration system in dangerous and under-regulated environments at the border and in sending communities, in labour recruitment networks, and in the U.S. workforce. Ultimately, the paper seeks to continue an ongoing conversation that challenges the criminalisation of migration which perpetuates vulnerability, and instead forwards rights-based policies that would promote shared prosperity.
\end{abstract}

Key Words: immigration reform, labour, human trafficking, enforcement, migrant protections

\footnotetext{
Many thanks to Neha Misra, the Senior Specialist on Migration and Human Trafficking at the Solidarity Center, for her helpful guidance and thoughtful contributions to this paper. Thanks are also due to the anonymous reviewers for the Anti-Trafficking Review for their thorough and insightful comments on this paper.
}

This is an open-access article distributed under the terms of the Creative Commons Attribution License (CC-BY). Under CC-BY license, the public is free to share, adapt, and make commercial use of the work. Users must always give proper attribution to the author(s) and the AntiTrafficking Review. 
Please cite this article as: A Avendaño and C Fanning, 'Immigration Policy Reform in the United States: Reframing the enforcement discourse to fight human trafficking and promote shared prosperity"', Anti-Trafficking Review, issue 2, 2013, pp. 97-118, www.antitraffickingreview.org.

Since 1997, over 1,000 people have been freed from conditions of forced labour and debt bondage, forms of human trafficking, in the tomato fields of southern Florida. ${ }^{2}$ Ricardo, a migrant worker who was forced to live in the back of a locked van, was among these trafficked workers. He was working off the debt he owed to his employer from an international labour contractor and punitive costs for living expenses. After more than a year, he escaped through a ventilation hatch in the vehicle. According to the Coalition of Immokalee Workers (CIW)-a communitybased organisation of approximately 4,000, mainly immigrant, members, in Florida's agricultural regions-the suffering of Ricardo and others allowed consumers to purchase tomatoes at US\$2 a pound in the supermarket. The average worker earns about 45 cents for a 32-pound bucket and many earn less. $^{3}$

The CIW has won notable gains through innovative organising strategies, but the structural economic and political forces that encourage this kind of exploitation extend far beyond the picking fields of Florida. Cross-border trafficking for the purposes of sexual and labour exploitation is very much linked to structural trends related to globalisation, inequality, and trade integration. ${ }^{4}$ Many violations stem from the convergence of the growing trend of international migration, the growth

2 R Patel, 'Supermarkets Must Take Stand Against Slave Conditions for Tomato Pickers', Tampa Bay Times, 16 February 2010.

3 Coalition of Immokalee Workers, 'About CIW', 2012, http://www.ciwonline.org/about.html.

4 See: Global Alliance Against Traffic in Women, 'Beyond Borders: Exploring Links between Trafficking, Globalisation, and Security', GAATW Working Papers Series, 2010, pp. 5-6. 
of largely unregulated international labour recruitment networks, and the emphasis of the global economy on cheap labour costs. ${ }^{5}$ From forced sweatshop labour in Southeast Asia, to indentured servitude in isolated U.S. worksites, 'layers of small-time labor procurers and contractors who work for what appear to be respectable business people who, in turn, work for others in a chain that often leads to multinational corporations'. ${ }^{6}$ These layers of subcontracting often protect those on top who profit from trafficking for labour exploitation from culpability, while those at the bottom exist in an underground, under-regulated environment. In the U.S., this is further reinforced by lax enforcement of labour protections and a dysfunctional immigration system that limits labour mobility.

In the U.S. debate around immigration policy, however, lawmakers tend to conceive of anti-trafficking protections as a segmented issue within the overall immigration system, instead of incorporating them into an overall frame that recognises the interplay between work, migration and exploited populations. This is especially true on the issue of border controls, where a 'law and order' narrative on border security dominates the U.S. political discourse.

Scholars have recognised the limitations of efforts to eliminate trafficking that are based on a high degree of regulation and criminalisation of cross-border movement. ${ }^{7}$ When the state forwards a dual mandate for enforcement agencies of restricting immigration and fighting human trafficking, it implicates itself

5 The total number of international migrants has been increasing in recent years. In 2005, there were an estimated 191 million migrants in the world, compared to 214 million in 2010. See: International Organization on Migration, World Migration Report 2011: Communicating effectively about migration, July 2011, p. 49, accessed from http://publications.iom.int/bookstore/ index.php?main_page=product_info\&products_id=752.

6 J Gray Pope, 'A Free Labor Approach to Human Trafficking', University of Pennsylvania Law Review, vol. 158, 2010, p. 1856.

7 J Chacon, 'Tensions and Trade-offs: Protecting trafficking victims in the era of immigration enforcement', University of Pennsylvania Law Review, vol. 158, 2010, p. 1615. 
in producing vulnerability. ${ }^{8}$ The enforcement of immigration laws often competes with the goal of preventing human trafficking by criminalising migration and marginalising migrant communities from protections. Even when migrants enter the U.S. with work authorisation, immigration policies produce similar vulnerability by tying immigration status to a single employer. Thus, some have advocated for a 'free labour' approach to combat human trafficking, whereby policies that facilitate mobility and empower workers should be encouraged over strict enforcement mechanisms. ${ }^{9}$ In the current U.S. political context, it is worth revisiting the conversation on delinking enforcement from protections and challenging the discourse of migrant criminality that perpetuates misguided policies. ${ }^{10}$

At the time of this writing (July 2013), the U.S. Senate has passed the Border Security, Economic Opportunity, and Immigration Modernization Act (S. 744) in a 68-32 vote. The much-awaited bill is the product of countless political compromises from many diverse groups, and although far from perfect, it is a significant improvement from previous attempts at immigration policy reform. Most notably, the bill codifies a roadmap to citizenship for a majority of the more than 11 million undocumented immigrants currently living in the U.S. It also includes important language on foreign labour contractors which requires they register with the Department of Labour (DOL), requires employers notify the $\mathrm{DOL}$ when using a foreign labour contractor, bans recruitment fees, and mandates contractors pay a bond to cover legal claims against the recruiter.

However, Democratic lawmakers conceded an amendment to the bill that dramatically increased funding for border security in order to gain Republican support. ${ }^{11}$ The bill now mandates

8 B Anderson, 'Where's the Harm in That? Immigration enforcement, trafficking, and the protection of migrants' rights', American Behavioral Scientist, vol. 56, no. 9, September 2012.

9 See: J Gray Pope, 'A Free Labor Approach to Human Trafficking', University of Pennsylvania Law Review, 2010.

10 See: J Chacon, 'Tensions and Trade-offs', 1628.

11 Known as the Corker-Hoeven Amendment. 
the Secretary of Homeland Security implement a 'comprehensive southern border security strategy' before undocumented immigrants who earn provisional status under the bill are able to apply for citizenship. The strategy calls for an increase in the number of Customs and Border Patrol (CBP) agents by 20,000 (doubling the current number of agents), mandates the construction of 700 miles of fencing along the U.S.-Mexico border, funds the installation of camera systems, surveillance towers, and ground sensors among other security measures. Additionally, it requires all employers to use an electronic system of employment verification to block undocumented immigrants from working in the U.S. and an entry-exit verification system at every air and sea port. In seeking to win the support of his fellow Republicans, pro-reform Senator John McCain of Arizona assured sceptics that 'we'll be the most militarized border since the fall of the Berlin Wall'. ${ }^{12}$ In order to become law, the bill will need to be voted on in the more conservative House of Representatives, where its fate is uncertain.

In this important political moment, anti-trafficking, labour, and migrant rights advocates must continue to forward a shared analysis of comprehensive policy proposals that empower migrants and challenge the current enforcement framework. The foreign labour contractor provision in the bill was forwarded by a diverse group of mostly U.S.-based labour and antitrafficking groups-many in the International Labour Recruitment Working Group (ILRWG) and the Alliance to End Slavery and Trafficking (ATEST)-who worked closely with legislators to get strong recruitment regulations included in the bill. ${ }^{13}$ Yet, with the last-minute addition of strict

12 D Strauss, 'Sen. McCain: US will have "most militarized" border since Berlin Wall', The Hill, 25 June 2013.

13 The Alliance to End Slavery and Trafficking (ATEST) is a coalition of U.S.-based human rights organisations working to end modern-day slavery and human trafficking; ATEST members include: the Coalition of Immokalee Workers (CIW), Coalition to Abolish Slavery \& Trafficking (CAST), End Child Prostitution and Trafficking - USA (ECPAT-USA), Free the Slaves, International Justice Mission (IJM), Not For Sale Campaign, Polaris Project, Safe Horizon, Solidarity Center, Verité, Vital Voices Global Partnership, World Vision, and former U.N. Goodwill 
enforcement language and the possibility that policy proposals will move further to the political right, other aspects of the immigration system may continue to put migrants at risk. Regardless of whether the bill passes, the growing focus on halting irregular migration, preventing access to work, and enforcing the temporary status of migrant workers will continue to remain a large part of the discourse. In order for the U.S. government to more effectively prevent human trafficking and get optimal societal outcomes from immigration, a stringent 'law and order' approach needs to be replaced with policies that both improve the proposed bill and create pathways to prosperous and fair working conditions.

This paper will attempt to continue a conversation on shifting the enforcement narrative in the U.S. by borrowing a key paradigm of the anti-trafficking community-the four Ps: prevention, protection of victims, prosecution of traffickers, ${ }^{14}$ and partnership as a framework to combat trafficking in persons. ${ }^{15}$ In the following sections, we will explore current shortcomings in immigration policy, provisions in the bill, and policy proposals that reflect this frame to protect and empower migrants at the border, in migrant origin communities, in international labour recruitment networks and in temporary worker programmes.

Ambassador Julia Ormond. The ILRWG is the first coordinated effort to strategically address abuses in international labour recruitment across visa categories; its members include: the AFL-CIO, the American Federation of Teachers, Centro de los Derechos del Migrante, CAST, the Department for Professional Employees, Economic Policy Institute, Farm Labour Organizing Committee, Farm Worker Justice, Global Workers Justice Alliance, National Domestic Workers Alliance, National Employment Law Project, National Guestworker Alliance, Safe Horizon, SEIU, the Solidarity Center, the Southern Poverty Law Center, Unite-Here, Verite, Free the Slaves, Polaris Project, and Vital Voices.

14 'Prosecution' should be broadened to encompass the promotion of 'rule of law' so that law enforcement professionals are trained to identify victims of trafficking and victims are aware of their rights under the law. See: American Bar Association, Rule of Law Initiative, http://www.americanbar.org/ advocacy/rule_of_law.html.

15 See: 'Four "Ps": Prevention, Protection, Prosecution, Partnerships', U.S. Dept. of State, retrieved July 2013, http://www.state.gov/j/tip/4p/index.htm. 


\section{Preventing Human Trafficking and Empowering Migrants across the U.S.-Mexico Border}

The proposed increased militarisation of the U.S.-Mexico border-at an estimated cost of over 30 billion dollars over 10 years-comes despite the fact that CBP's budget has been dramatically expanding for years and does little to protect migrants, prevent trafficking, or build partnerships that empower migrants. In 2011, CBP's budget, in inflation-adjusted dollars, grew by 102 per cent since 2005 and 579 per cent since 1992. Additionally, the number of CBP agents has grown five-fold in the last decade. ${ }^{16}$ Ramped up border enforcement has come at a high human cost. Migrants must take increasingly remote routes across the border, as barriers and enforcement close off safer and well-travelled options. Since 1994, more than 5,600 unauthorised migrants have died in the desert in unsafe crossings, ${ }^{17}$ and at least 18 individuals have died since January 2010 as a result of 'alleged excessive use of force by [CBP] officials'. ${ }^{18}$

Additionally, many express concerns that tight border controls make it difficult for asylum seekers to enter, thereby fuelling an underground economy in human smuggling and trafficking. Cross-border mobility becomes a business when legal migration is impossible. It is estimated that international human trafficking is a 32 billion dollar a year industry; however, its hidden nature

16 A Isacson and M Meyer, Beyond the Border Buildup: Security and migrants along the US-Mexico border, Washington Office on Latin America, April 2012, http://justf.org/files/Beyond_the_Border_Buildup_hires.pdf; GAO-12-106R: Border Security Fencing, Infrastructure, and Technology Fiscal Year 2011 Expenditure Plan, 14, retrieved July 2013, http://www.gao.gov/assets/590/ 586348.pdf.

17 'Human Rights Violations on the United States-Mexico Border', ACLU Statement submitted to the UN High Commissioner for Human Rights, 25 October 2012, retrieved August 2013, http://www.aclu.org/files/assets/ 121024_aclu_written_statement_ochcr_side_event_10_25_12_final.pdf.

18 ACLU, 'United States' Compliance with the International Covenant on Civil and Political Rights', Testimony to $107^{\text {th }}$ Session of the Human Rights Committee, Geneva, 10 December 2012, p. 11. 
makes it difficult to investigate and gather reliable data. ${ }^{19}$

The need for these dramatic increases in border security funding is not justified by facts on the ground. Net migration from Mexico is now zero or slightly negative. ${ }^{20}$ Additionally, border communities in California, Arizona, New Mexico, and Texas, including major cities such as San Diego and El Paso, are among the safest in the country, with crime rates associated with breaking and entering, trespassing, and car theft well below the national average. ${ }^{21}$ Many migration advocates and thinkers have proposed that a policy of 'no borders' and freedom of mobility would better promote the human rights of migrants. While this could be the case, in the U.S. political context, border controls will continue for the foreseeable future and will likely become more strident. ${ }^{22}$ Despite its harmful provisions, S. 744 has some bright spots related to border controls. One thousand emergency stations would be established where migrant deaths occur most frequently. Independent child welfare professionals would be placed in border patrol stations to provide basic humanitarian assistance to unaccompanied children, and ensure the appropriate screening to identify victims of human trafficking. ${ }^{23}$ For the first time, the Department of Homeland Security (DHS, the department that houses the CBP) would be required to issue policies governing the use of force by personnel along with a complaint process for dealing with

19 A Pécoud and P de Guchteneire, 'International Migration, Border Controls, and Human Rights: Assessing the relevance of a right to mobility', Journal of Borderlands Studies, vol. 21, no.1, Spring 2008, p. 72; Polaris Project, 'Human Trafficking Statistics', 2012, retrieved July 2013, http://www.cicatelli.org/ titlex/downloadable/Human\%20Trafficking\%20Statistics.pdf.

20 Southern Borders Communities Coalition, 'Border Briefing: Why we need better borders, not more border enforcement', February 2013, retrieved July 2013, http://soboco.org/border-briefing-why-we-need-better-borders-not-moreborder-enforcement/\#note-885-3.

21 Ibid.

22 For example, see: B Anderson, N Sharma and C Wright, 'Editorial: Why No Borders?' Refuge, vol. 26, no. 2, 2011.

23 National Immigrant Justice Center, 'The Good \& Bad in S. 744: Border Security, Economic Competitiveness, and Immigration Modernization Act of 2013', 2013, retrieved July 2013, http://www.immigrantjustice.org/immigrationreform/ s744analysis\#.UdwWfUGyD_I. 
excessive use of force. Agents working within 100 miles of the U.S.-Mexico border must receive training on civil, constitutional, human, and privacy rights; use of force; screening of vulnerable migrants; cultural and social sensitivity of border communities; impact on border communities; and environmental concerns. ${ }^{24}$ The bill also includes training for Border Community Liaison Officers to foster relationships, consult with and receive performance assessments from border communities. ${ }^{25}$

Before the passing of this new bill, the CBP has already dedicated an office to human trafficking, coordinated training for agents in the field to recognise trafficking victims, and pursued public education efforts like the 'No Te Engañes/Don't Be Fooled' campaign, which displays anti-trafficking ads in Mexico and Central America and at border crossing stations. ${ }^{26}$ This initiative is part of the 'Blue Campaign' in which DHS engages its various agencies, law enforcement, NGOs, and the private sector in an effort to combat human trafficking. DHS agencies also produce training and informational campaign material, provide victim assistance and conduct investigative efforts, and establish partnerships, outreach, and online resources. ${ }^{27}$

Similarly, the U.S. government offers an information pamphlet to applicants for temporary visa programmes in the U.S. that contains information about U.S. labour rights, including the freedom of association and right to collective bargaining, as well as specific information about rights under the visa programmes. U.S. consular officials must confirm that the

\footnotetext{
Section 1111 of the Senate bill.

Section 1112 of the Senate bill.

See: M Ahlers, 'Dramatic TV Ads Sell Anti-Human Trafficking message: "Don't Be Fooled"', CNN, 20 June 2011, retrieved July 2013, http://edition.cnn.com/ 2011/WORLD/americas/07/19/us. human.trafficking.campaign/index.html.

27 See: U.S. DHS, 'Blue Campaign', 2013, retrieved July 2013, https:// www.dhs.gov/blue-campaign/blue-campaign.
} 
applicant has received, read and understood the pamphlet. ${ }^{28}$ The pamphlet directs workers who feel that their rights have been violated to contact one of two hotlines that assist victims of human trafficking. ${ }^{29}$

While these are laudable efforts, they land far from the goal of delinking enforcement and controls from antitrafficking efforts. Anti-trafficking programmes should aim to address the marginalisation of trafficked workers by creating processes for migrants to engage without the fear of enforcement. The Department of State (DOS) needs to expand its portfolio in this regard by increasing the number of labour officers and attachés in the field and expand site visits to labour recruitment centres. Its consulates should build partnerships through the engagement of Mexican institutions and civil society groups, ${ }^{30}$ especially in border regions and communities with heavy migration. Because enforcement of rights-based policies largely depends on workers being able to report violations, these kinds of initiatives prevent abuse and protect migrants crossing the border.

In the next two sections, we will more explicitly explore policies and improvements to $\mathrm{S}$. 744 related to the recruitment of workers from their home countries and legal temporary work programmes in the U.S.

28 United States Department of State, 'Corrected Copy - Pamphlet and Training for the William Wilberforce Trafficking Victims Protection Reauthorization Act of 2008'.

29 U.S. Department of State, 'Are You Coming to the United States Temporarily to Work or Study?' 2012, retrieved July 2013, http://travel.state.gov/visa/temp/ pamphlet/pamphlet_4578.html.

30 For example, the Centro de Los Derechos del Migrante, based in Mexico City, with offices in Baltimore, Oaxaca, and Zacatecas meets with more than 6,000 people in 23 states across Mexico to ensure that migrants know their rights before they cross the border, http://www.cdmigrante.org/about-cdm/organizationalbackground-history/. 


\section{Regulating International Labour Recruiters}

Each year, hundreds of thousands of people are recruited from abroad under a vast array of temporary visas to work in a wide range of industries in the U.S. Regardless of their visa, internationally recruited workers face common patterns of abuse, including fraud, discrimination, economic coercion and, in some cases, human trafficking. ${ }^{31}$ Beginning in a migrant's home country, recruitment agencies, visa sponsors, or employers charge high rates, sometimes between US\$1,000 and US\$20,000 in legal and illegal fees, for securing employment-based visas. The industry ranges in scale from large, registered recruitment firms to diffuse networks of agents and subagents operating outside state regulatory regimes. Often, workers have to borrow money at predatory interest rates or mortgage their homes to pay the fees. This debt, coupled with the fact that guest workers are frequently housed in isolated labour camps and restricted to certain employers to maintain their immigration status, creates an environment where trafficking thrives. ${ }^{32}$

S. 744 addresses many of these abuses in a subtitle that is specifically designed to prevent trafficking of internationally recruited workers (Subtitle F: Prevention of Trafficking in Persons and Abuses Involving Workers Recruited Abroad). Among other things, these provisions require transparency in the recruitment chain, including disclosure to workers of the terms and conditions of employment, a signed copy of the contract with the employer, the type of visa under which the worker will be employed, the existence of any labour disputes at the place of employment, as well as information on protections for victims of trafficking. The bill establishes a government complaint process and a right to bring a civil action after a third violation. ${ }^{33}$ It also prohibits discrimination, including

31 See: International Labour Recruitment Working Group, 'The American Dream up for Sale: A blueprint for ending international labour recruitment abuse', January 2013, retrieved July 2013, http://www.cdmigrante.org/wp-content/ uploads/2013/02/Final-E-version-ILRWG-report2.pdf.

32 Ibid.

33 Section 3610. 
blacklisting, and makes it unlawful for an employer or foreign labour contractor or agent to charge any fee (this includes visa fees, transportation fees, legal expenses, placement fees and other costs) to a worker for any foreign labour contracting activity. Because employers may use labour recruitment agencies to reduce their responsibility for the workers they employ, often ignoring the unscrupulous tactics used by recruiters, the bill expands liability to the ultimate employer; although these provisions are very weak if the employer used DOL-registered recruiters and can claim they were not acting in reckless disregard of the provisions.

If implemented, these provisions would offer significant protections for recruited foreign workers. Anti-trafficking advocates working on recruitment issues, including the authors of this paper and members of the ILRWG and ATEST, worked closely with legislators to get the regulatory language included in the bill. However, the bill has recruitment language that could be improved, especially as it relates to the J-1 Exchange Visitor Program.

There are 14 sub-categories of $\mathrm{J}-1$ visas, covering a wide array of occupations. In terms of annual admissions, the $\mathrm{J}-1$ programme is the largest U.S. guest worker programme. In 2010, the J-1 visa covered nearly 320,000 visitors. The summer, work, travel programme, the interns/trainees programme, and au pairs programme alone bring in more than 150,000 workers, more than the $\mathrm{H}-2 \mathrm{~B}$ and $\mathrm{H}-2 \mathrm{~A}$ visa programmes (for temporary and seasonal low-wage work or agricultural work, respectively) combined. ${ }^{34}$ During Senate negotiations, the au pair agency lobby, summer camp operators, hotels and 'cultural exchange' groups worked to get an exemption for the J-1 visa programme, falsely claiming the law would move the J-1 visa into a work

34 D Costa, EPI Briefing Paper: 'Guest Worker Diplomacy: J Visas receive minimal oversight despite significant implications for the U.S. labour market', Economic Policy Institute, July 14, 2011; U.S. Department of State, Bureau of Consular Affairs, 'Exchange Visitor Visas', 2011; ' $\mathrm{J}-1$ Visa: Basic facts and figures’, U.S. Department of State, retrieved July 2013, http://j1visa.state.gov/ basics/facts-and-figures/. 
visa category and that this would cause a substantial increase in fees to families and employers and perhaps even end the programme. ${ }^{35}$ In reality, employers already pay thousands of dollars in fees to sponsor agencies to cover travel, visa processing, and a 'programme fee'. As these agencies also charge fees to the $\mathrm{J}-1$ recipients to cover the exact same costs, they had a clear interest in protecting their profit margins.

In the end, J-1 visa holders came away with fewer protections in the bill than other recruited workers. While they will receive information on the terms and conditions of employment before they leave their home countries, have protection from retaliation and have the possibility of immigration relief for reporting recruitment abuse, they will still face recruitment fees, capped at the discretion of DOS. Fees are one of the main reasons workers are forced to stay in exploitative working conditions, some of which amount to debt bondage. Faced with the risk of having to return to their home countries in debt or with little salary to show for their efforts, recruited workers often feel they have no choice but to remain and endure the abusive working conditions. Despite its beginnings as a cultural exchange programme, J-1 workers have faced terrible working conditions. For instance, recently, student guest workers on J-1 visas walked out of three McDonald's restaurants in Pennsylvania after being forced to work shifts of up to 25 hours with no overtime pay, receiving inadequate housing, and being threatened with deportation when they raised concerns. ${ }^{36}$

In order to protect internationally recruited workers and prevent human trafficking and other exploitation, it is essential that the prohibition on fees and other protections for recruited workers remain in the bill. Leaving an entire visa category out of these protections creates a perverse incentive for unscrupulous employers to mistreat workers under the programme without fear of punishment. Yet, the J-1 issue is

35 See" 'Advocacy', The Alliance for International Educational and Cultural Exchange, retrieved July 2013, http://capwiz.com/alliance-exchange/home/.

36 JJ Rosenbaum, 'No More Captive Workers', Roll Call, June 10, 2013, retrieved July 2013, http://www.rollcall.com/news/no_more_captive_workers_ commentary-225472-1.html. 
just one feature of the broader structural issues with U.S. temporary worker programmes that promote relationships of dependency between migrants and their employers and sponsors. To move the debate toward a rights-based frame, these issues must be addressed.

\section{Rights-based Policies on Labour Migration}

Unlike border controls, which conjure up images of walls and detention centres, temporary worker programmes are often considered with an international development lens. In the social sciences, international migration is often viewed as a 'global flow' driven by economic, social, and political forces that occur across borders. ${ }^{37}$ In recent years, many scholars and advocates endorse some method of liberalising migration to spur development and meet the needs of transnational capital. For instance, the Global Forum on Migration and Development has served as a major hub of discussion on the issue of temporary circular migration and has moved governments to embrace labour market flexibility over rights protections. ${ }^{38}$ In the US, the Migration Policy Institute has furthered the idea of 'circular migration regimes' (an approach that would allow migrants to repeatedly move across borders for employment) as a 'triplewin'-that destination countries receive needed workers, origin countries receive development-friendly remittances, and migrants receive training and more 'opportunities for safer, legal migration from the developing world'. ${ }^{39}$

In U.S. policy, circular migration is reflected in temporary worker programmes. According to the ILO, 'There are...few real

37 M Teitelbaum, 'The Role of the State in International Migration', The Brown Journal of World Affairs, vol. 8, no. 2, 2002, p. 1.

38 I Omelaniuk, Global Perspectives on Migration and Development: GFMD Puerto Vallarta and beyond, Springer Science, 2012, p. 9.

39 D Agunias and K Newland, 'Circular Migration and Development: Trends, policy routes, and ways forward', Migration Policy Institute, April 2007, p. 2, retrieved July 2013, http://www.migrationpolicy.org/pubs/ migdevpb_041807.pdf. 
differences between temporary labour migration and circular migration movements/programmes to brand the latter as an innovative tool.' 40 As with temporary guest worker visa programmes, circular migration provides 'labour without people... making it easier for employers to exploit workers, and engage in flexible hiring and firing, in line with economic and business conditions, and short term savings in integration costs'. ${ }^{41}$ This asymmetric power balance is supported by the current U.S. immigration system, where temporary workers are prohibited a path to permanent residency or citizenship. Guest workers are tied by law to their employer and, because they can only remain in the US at the will of their employers, complaints can be precarious. Unscrupulous employers confiscate workers' passports and visas to ensure a submissive workforce. Workers who complain are often blacklisted, or threatened with deportation, which effectively nullifies workplace rights for these guest workers. ${ }^{42}$

In S. 744 some of these issues were addressed in negotiations on labour migration policy between the AFL-CIO and other trade unions and the U.S. Chamber of Commerce, representing business interests. At the behest of lawmakers, the parties eventually came to an agreement on a new ' $W$ visa' programme for non-seasonal, lower-skilled jobs. The idea behind the new programme is to create a 'dual-intent' visa, which would allow immigrant workers to come to the U.S. for both employment and residency, allowing for family reunification as well. ${ }^{43}$ The visa would give workers the ability to self-petition for a green card after a period of one year and freely change employers. It was agreed that wages were to be set at a rate that would not adversely affect the wages and working conditions of U.S.

40 P Wickramasekara, Circular Migration: A triple win or a deadend? ILO-ACTRAV, February 2011.

41 Ibid.

42 M Bauer and S Reynolds, Close to Slavery: Guest Worker Programs in the United States, Southern Poverty Law Centre, 2013.

43 A 'dual intent' visa allows a worker to come into the country with the intent to stay or leave. It also allows the worker to apply for permanent settlement. 
workers. To achieve these goals and to ensure transparency, it was agreed that the programme would include a database of employers with job openings that qualified for the programme. $W$ visa holders could then freely change employers with the full knowledge of the jobs available to them.

The bill also phases out the $\mathrm{H}-2 \mathrm{~A}$ temporary foreign agricultural worker programme, which permits employers to hire guest workers to fill agricultural jobs that last no longer than ten months. The $\mathrm{H}-2 \mathrm{~A}$ programme will be replaced with a new visa programme that provides a three-year visa to work in any agricultural job, including year-round industries such as dairy with an important new protection-for the first time some of the agricultural visas will be portable; workers will be free to leave an employer and work for another agricultural employer registered to participate in the programme. Undocumented farmworkers who have worked 100 days in the U.S. in the past two years will be able to apply for a 'blue card' (temporary residency) during an 18-month application period that will begin seven months after enactment.

However, these portability protections are not available to migrant workers in other visa programmes, like the $\mathrm{H}-2 \mathrm{~B}$ programme for temporary and seasonal work, the $\mathrm{H}-1 \mathrm{~B}$ for skilled work, or the J-1 visa. These protections must be expanded to all visa categories. Additionally, few of these programmes allow migrants to remain in this country and eventually become citizens. The bill, with its employment verification requirements that seek to block undocumented immigrants from working in the U.S. and its mandate to establish an entry-exit verification system for those in the U.S. on temporary work visas, creates enforcement mechanisms that perpetuate the temporary nature of these programmes. This will only perpetuate conditions of risk for migrant workers in guest worker visa programmes and will do nothing to protect them from the risk of human trafficking.

Instead of establishing a system that excludes migrants from rights, the focus should be on empowering workers and creating conditions of shared prosperity. Immigrant workers in the U.S., regardless of visa status, should have the ability and the legal 
tools available to move between employers, join together to better their working conditions, and access the same rights and protections as U.S. citizens-these principles, not enforced precarity, will contribute to preventing human trafficking and protecting migrant workers. Noncompliant employers and labour contractors, too, should be pursued and prosecuted by the federal government and barred from U.S. work visa programmes. These would need to reflect policies in the U.S. that support migrants as rights-holders and target exploitative and under-regulated worksites.

\section{Empowering Migrants in the United States}

Key to immigration policy reform must be a legalisation programme for undocumented immigrants, with a clear and broad roadmap to citizenship. From an anti-trafficking perspective, a path to citizenship is fundamentally important. This would empower immigrant workers to speak out against abuses without the fear of deportation. Secondly, as policy shifts towards inclusiveness, abusive employers would no longer have access to a large supply of exploitable workers, and, further, a channel to naturalisation is likely to encourage migrants to default on large amounts of illicit migration-related debt with less fear of retaliation and more access to justice. Workers in debt bondage would also have less incentive to work off the debt if there were a defined path for them to escape such a situation and gain legal residency and work authorisation. ${ }^{44}$ Unfortunately, S. 744 ties its legalisation provisions for a path to citizenship to its burdensome enforcement requirements. Immigrants who earn provisional status will only be able to apply for citizenship once the Department of Homeland Security and employers are meeting stringent targets related to border

44 G Friebel and S Guriev, 'Illegal Migration and Trafficking', Centre for Economic and Policy Research, 2002, pp.1-3, retrieved July 2013, www.researchgate.net/ publication/228378217_human_trafficking_and_illegal_migration/file / 32bfe510a82d51c276.pdfa. 
and employment enforcement. Not only do undocumented immigrants have nothing to do with border security, but the requirements prevent migrants from accessing their full rights and equal protections.

For a legalisation programme to be most effective, it would have to be accompanied by enhanced monitoring of labour laws. One of the greatest deficiencies of statutory protection is underenforcement, particularly in low-wage industries. Many unscrupulous employers simply calculate the cost of potential penalties into a low-rate business model. The federal government's allocation to DOL to enforce these laws is miniscule. The Economic Policy Institute has found that the amount Congress appropriated to enforce labour laws and regulations amounted to only US\$1.6 billion-about 9 per cent of what was spent enforcing immigration laws last year. Furthermore, the Wage and Hour Division, the primary enforcer of non-safety related labour standards, has only about 1,100 inspectors, who are responsible for protecting over $135,000,000$ workers in more than 7,300,000 establishments throughout the United States and its territories. ${ }^{45}$ Meanwhile, in only New York, Chicago and Los Angeles, researchers found that workers in low-wage industries in the three cities lost over US\$56 million per week due to wage theft. ${ }^{46}$ Given this, not only is there a need for increased labour inspection, there also needs to be a sufficient number of labour inspectors with special training to recognise signs of human trafficking.

As the International Labour Organization (ILO) has noted, 'Where labour standards are rigorously adhered to, workers are well unionized and labour laws are monitored and enforced

45 D Costa, 'Huge Disparity in Funding for Immigration Enforcement vs. Labour', Economic Policy Institute, 23 January 2013, retrieved July 2013, http://www. epi.org/blog/funding-disparity-immigration-enforcement-labour-standards/.

46 A Bernhardt, R Milkman, $N$ Theodore, D Heckathorn, M Aver, J DeFilippis, A Gonzalez, V Narro, J Perelshteyn, D Polson and M Spiller, Broken Laws, Unprotected Workers: Violations of employment and labour laws in America's cities, Centre for Urban Economic Development at UIC, National Employment Law Project and UCLA Institute for Research on Labour and Employment, New York, 2009, retrieved July 2013, www.nelp.org/page/-brokenlaws/ BrokenLawsReport2009pdf. 
- for all workers, indigenous or migrant - the demand for trafficked people and services is likely to be low. ${ }^{47}$ There need to be better protections in the U.S. for collective bargaining. Collective bargaining is an effective antitrafficking tool; when workers can collectively bargain, they can more effectively institutionalise workplace monitoring and reverse exploitative conditions. Since 2000 , unions in the U.S. have pushed for comprehensive immigration reform, in part, for this reason. The AFL-CIO reversed its longstanding restrictionist policies after seeing employers self-report to immigration authorities and use 'sanctions' to undermine organising drives among undocumented immigrants.

Finally, emphasis should be placed on systems that would allow victims to pursue prosecution of their employers, rather than on prosecuting migrants without legal status. S. 744 is mixed on this point. It expands the tools available to migrant survivors or witnesses of violent crimes like trafficking by increasing the number of $U$ visas available for this purpose from 10,000 to 18,000 . It also expands access to work permits for survivors of violence and trafficking and requires DHS to adjudicate individuals' asylum, U visa, Violence Against Women Act, or other protection-based claims before prosecuting them for illegal entry or reentry. ${ }^{48}$ To improve on this, the US should adopt the Council of Europe Convention's norm and allow a period of reflection before testimony and should expedite processing for visas along with expanding their number. ${ }^{49}$ The TVPA, for instance, enhances criminal penalties for traffickers and offers trafficking victims a special $T$ visa, which gives these victims a temporary stay and a path to citizenship to ensure the prosecution of traffickers. While this act offers important protections, it is notoriously difficult to procure a

47 ILO, 'Trafficking in Human Beings: New approaches to combatting the problem', May 2003, p. 4, retrieved July 2013, http://www.popcenter.org/problems/ trafficked_women/PDFs/International\%20Labour\%200ffice_2003.pdf.

48 National Immigrant Justice Center, op. cit.

49 Mark P. Lagon, 'The Global Abolition of Human Trafficking: The indispensable role of the United States', Georgetown Journal of International Affairs, Winter 2011, p. 94 
T visa; from 2002 to 2012 , only 3,269 T visas were approved for victims. ${ }^{50}$

Somewhat schizophrenically, S. 744 also seeks to impose harsh criminal penalties on people who migrate illegally to the U.S., including up to a year in prison and three years for reentering after being deported, and empowers local police to enforce federal immigration law by allowing DHS to share information with local law enforcement agencies about individuals who have overstayed their visas. ${ }^{51}$ In 2011 alone, 82,250 individuals were criminally prosecuted for immigration violations, constituting over 50 per cent of all federal prosecutions, costing $\$ 1,023,615,633$, and resulting in Latinos now representing more than 50 per cent of the federal prison population. ${ }^{52}$ This would only expand under S. 744 and undermines the important protections discussed above. By criminalising migration and residency in this way, migrants are forced to live and work in the shadows for fear of being detained and deported. The U.S. should align with the recommendation of the UN Special Rapporteur on the Human Rights of Migrants, Francois Crepeau, who has called for an end to the detention of immigrants, except in exceptional cases when no other options are available. ${ }^{53}$

\section{Conclusions}

Human trafficking is one of the basest social problems in the modern world. With the Senate passage of S. 744, antitrafficking, migrant, and labour advocates have a unique

50 A Siskin and L Sun Wyler, 'Trafficking in Persons: U.S. policy and issues for Congress', Congressional Research Service, 19 February 2013, p. 21.

51 National Immigrant Justice Center, op. cit.

52 Detention Watch Network, 'Detention Watch Network Disheartened by Senate Immigration Bill', 27 June 2013, retrieved July 2013, http:// www. detentionwatchnetwork. org/node/3535.

53 See: UN Human Rights Council, 'Report of the Special Rapporteur on the human rights of migrants, François Crépeau', 2 April 2012, retrieved July 2013, http: / /www.ohchr.org/Documents/HRBodies/HRCouncil/RegularSession/Session20/ A-HRC-20-24_en.pdf. 
opportunity to challenge the current U.S. discourse on enforcement and make the case for a rights-based agenda on immigration reform by capitalising on a global consensus against this form of modern day slavery. As outlined here, a rights-based agenda would include, at a minimum, enhanced monitoring of CBP practices at the border and the extension of their anti-trafficking initiatives to include partnerships with Mexican institutions; the regulation of international labour recruiters; mobility protections under work visa programmes and an end to programmes that enforce the temporary nature of labour migration; a robust roadmap to citizenship; and increased enforcement of labour protections and enhanced tools for migrants to report abuses.

By incorporating anti-trafficking language-most notably the four Ps: prevention, protection of victims, prosecution of traffickers, and partnerships-and extending it to implicate the entirety of immigration policy reform proposals, advocates can form a sharper critique of the enforcement measures and labour migration programmes that perpetuate the structures that allow human trafficking to thrive. Migrant workers need to be empowered by policies that allow them to exercise the ability to change their working conditions and have the freedom to move from abusive situations, without the fear of prosecution for immigration-related violations. Only when migrants have full rights and protections equal to all workers in the U.S. will we truly be able to root out trafficking in the U.S. and create conditions of shared prosperity through our immigration system.

Ana Avendaño is an assistant to the President and Director of Immigration and Community Action at the AFL-CIO. She handles international matters related to migration for the AFL-CIO. She also advises national and local union leaders on immigration policy and other matters that impact immigrant workers. She liaises closely with community partners, oversees the work related to the AFL-CIO's Worker Center Partnerships and other 
grassroots and community outreach. Ms. Avendaño was formerly an Associate General Counsel at the AFL-CIO and the Assistant General Counsel to the United Food and Commercial Workers International Union. She is a graduate of Georgetown University Law Center and the University of California at Berkeley.

Email: aavendan@aflcio.org

Charlie Fanning is a writer and researcher in the office of the President at the AFL-CIO. He supports the strategic objectives of the AFL-CIO with policy, economic, and political research related to immigration, community action, and worker representation. He also assists with advocacy on international matters related to migration for the AFL-CIO. Mr. Fanning is a graduate of the Georgetown School of Foreign Service and Florida Southern College.

Email: cfanning@aflcio.org 
DOI: 10.14197/atr.20121326 